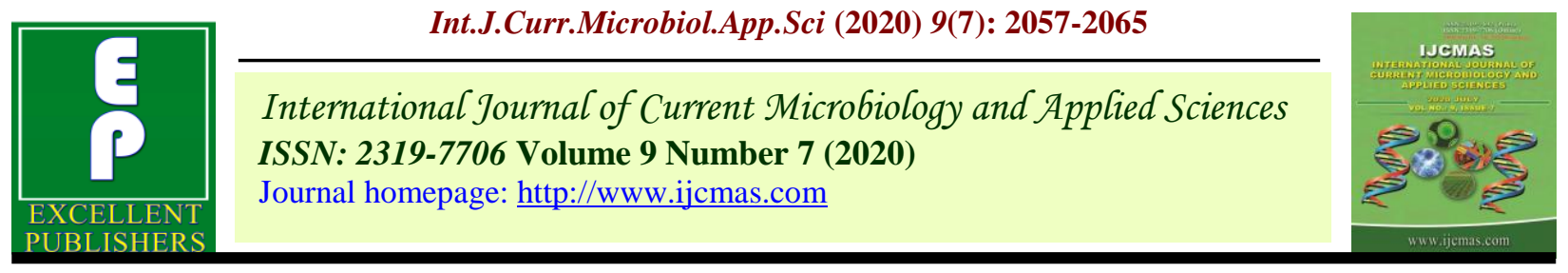

Review Article

https://doi.org/10.20546/ijcmas.2020.907.237

\title{
Status of Institutional Credit Disbursement of Agricultural Sector in Odisha, India
}

\author{
Shruti Mohapatra* and Raj Kishore Mishra
}

Department of Agricultural Economics, OUAT, Bhubaneswar, Odisha, India

*Corresponding author

\begin{tabular}{|l|}
\hline Ke y w o r d s \\
$\begin{array}{l}\text { Institutional credit } \\
\text { disbursement, } \\
\text { Agricultural sector, } \\
\text { Commercial banks }\end{array}$ \\
\hline Article Info \\
\hline $\begin{array}{l}\text { Accepted: } \\
\text { 17 June } 2020 \\
\text { Available Online: } \\
\text { 10 July } 2020\end{array}$ \\
\hline
\end{tabular}

\section{A B S T R A C T}

This paper attempts to analyse the status of agricultural credit disbursement in the state of Odisha. The analysis has revealed that the credit disbursed for the crop loan, term loan and allied loan has been increased over the period of time. The growth rates in crop loan disbursement among the institutional sources showed that co-operative banks registered significantly highest growth of 18.05 per cent followed by commercial banks at 17.27 per cent and regional rural banks at 7.22 per cent and all significant at different per cents of probability level. Commercial banks were the major sources of term credit followed by co-operative banks and RRBs. The percentage of NPA to total outstanding has been recorded highest in case of regional rural banks followed by co-operative banks and commercial banks. Over the period of time it has been seen a gradual decrease in percentage of NPA to total outstanding in every cases of banks. The study has suggested improved modifications and policy measures that government should start for simplification of the procedure for a better access to agricultural credit of smallholders and less-educated/illiterate farmers.

\section{Introduction}

Agriculture is the back bone of Indian economy which plays an important role in the economic development of India. It is the source for livelihood of more than 65 per cent of the country's population and it contributes less than 20 per cent to GDP, with a sizable share of exports. Agricultural credit started depicting a growth after bank nationalization in the country and it has been growing continuously since then (Golait, 2007). This has resulted in a significant increase in the access of rural cultivators to institutional credit and the contribution of informal agencies as credit sources have declined. Agricultural credit being one of the critical inputs and an effective means of rural development in India, innovations in agricultural credit market has gained importance over the years (Shraddha, 2013). The share of institutional agencies in the total 
agricultural credit supply was 7 per cent in 1951, which rose to 66.3 per cent in 1991. The next decade witnessed a slight decline in its share and it fell to 64.3 per cent in 2002-03 (Kumar et al., 2010). These initiatives have had a positive impact on the flow of credit to agriculture. The major milestones in improving the rural credit are acceptance of Rural Credit Survey Committee Report (1954), nationalization of major commercial banks (1969 \& 1980), establishment of RRBs (1975), establishment of National Bank for Agriculture and Rural Development (NABARD) (1982) and the financial sector reforms (1991 onwards), Special Agricultural Credit Plan (1994-95), launching of Kisan Credit Cards (KCCs) (1998-99), Doubling Agricultural Credit Plan within three years (2004), and Agricultural Debt Waiver and Debt Relief Scheme (2008). These initiatives had a positive impact on the flow of agricultural credit. However, the inadequacy of credit to agriculture is often a hotly debated topic in India (Mohan 2004). The share of different institutional agencies in the agricultural credit flow revealed that the institutional sources of agricultural credit flow have undergone a structural change in India. The share of scheduled commercial banks (SCBs) has increased from a mere 1.9 per cent in 1972-73 to 73 per cent in 2008-09. There seems to be a direct relationship between institutional credit flow and the level of agricultural development in India.

The ground Level Credit (GLC) flow in Odisha state under Priority Sector was depicted to follow an increasing trend over the last six years, except for the years 2013-14 and 2016-17 in which the compound annual growth in total agricultural credit flow has been noticed 20.77 per cent and the credit flow to MSME sector has also shown a rising trend except for 2016-17 but growth in ground level credit flow to other priority sector has been fluctuating. For the year
2018-19 annual credit plan for Odisha state has recorded a total credit flow of ' 71419.85 crore under Priority Sector, out of which 38378.41 crore is under agriculture sector. Taking overall credit structure in to consideration it has stated that the total credit to farm sector has increased at a CAGR of $22 \%$ over the last decade. The contribution of cooperative banks accounted for $67 \%$ of total crop loan disbursed in the State, whereas Commercial Banks had a share of about $94 \%$ in the Agriculture Term Loan during 2017-18 (NABARD state focus paper). As per NSSO (70th Round - January to December 2013), $59.9 \%$ of rural households availed loan from institutional sources and 56\% availed loans from non-institutional sources. According to Bharat Microfinance Report 2017, there are 28 major MFIs operating in the State with total loan outstanding amount 3564 crore.

Agriculture is an important part of economy of Odisha as it provides topography highly suitable for agricultural activities. It has been estimated that about 80 per cent of the total population in Odisha is dependent upon agriculture. For many rural residents of Odisha, agriculture is the major occupation. However, available resource base and the capacity to generate sufficient levels of financial resource within the rural sector particularly in agricultural sector are, however limited at present. Institutional financing is viewed from this angle as a principal resource of external finance to support agriculture sector in a planned manner. Institutional credit enables the farmer to procure the necessary wherewithal of production and creates conducive climate for enhanced output. But, agricultural credit is said to be effectively used, only when the availed credit induces sufficient marginal value to the farmers produce in order to facilitate the repayment of credit, along with the due interest amount, within the stipulated time to the agricultural credit institution. Keeping in 
view the place of agriculture in the study area, the attempt is to assess the disbursement of credit in the state of Odisha.

\section{Agriculture in Odisha: issues and challenges}

The agriculture in Odisha is facing several challenges which includes (a) Low productivity due to fragmentation of land holding pattern, (b) Mostly focused on cereal production, (c) lack of research and development support, (d) One third of agriculture land is alkaline or saline,(e) Insufficient and improper use of inputs, (f) Credit flow is skewdly distributed across the districts, (f) Highly fragmented markets, (g) Microfinance/SHGs initiatives not focusing on agriculture, and (h) Low use of Information and digital technology in agriculture.

Scope of Agriculture in Odisha: (i) There are ample scope for crop diversification considering the variety of agro climatic zones in the state, (ii) The low use of fertilizer can be strengthen as large areas can be brought under organic agriculture which is characterized by growing demand and commands a premium price in the global and domestic markets, (iii) Agro processing and agribusiness have good value addition and employment generation potential. In the long term, agriculture would not be able to sustain the nearly 60 percent of the population involved in agriculture and hence, there is need to create more opportunities in the agro industries sector (Khan, 2008).

\section{Agency wise flow of credit disbursement in Odisha}

An over view of the results in Table 1 showed that cumulative crop loan disbursement together by commercial banks, co-operatives and regional rural banks together during the study period was Rs. 10770.21 crore. Among the institutional sources, co-operative banks were the largest contributing agencies with Rs. 69,22.23 crore (64.27 per cent) and registered increase in credit advance from Rs. 2876.52 crore during $2009-10$ to Rs. 12810.33 crore in 2018-19. Thus, showed an increase in share over a period from 61.31 per cent (2009-10) to 68.07 per cent (2012-13) and then found declining from 55.7 per cent in the year 2015-16 but then again started increasing up to 68.39 per cent in $2018-19$ of the crop loans among all institutions. This was followed by commercial banks with Rs. 2839.51 crore (26.36 per cent) which registered an increase in credit advance from Rs. 1086.56 crore in $2009-10$ to Rs. 4557.26 crore in 2018-19. However, it could be observed that proportion of crop loan advanced by commercial banks to the total crop loan by all institutions has increased gradually from 23.15 per cent in $2009-10$ to 34.79 per cent in 2015-16 and then started declining to 24.33 per cent in 2018-19.

Regional rural banks contributed Rs. 10,08.44 crore (9.36 per cent) with an increase from Rs. 728.53 crore in $2009-10$ to Rs. 1364.88 crore in 2018-19. But, the proportion of crop loan advanced by regional rural banks to the total crop loan by all institutions declined from 15.53 per cent in 2009-10 to 7.29 per cent in 2018-19. The growth rates in crop loan disbursement among the institutional sources showed that co-operative banks registered significantly highest growth of 18.05 per cent followed by commercial banks at 17.27 per cent and regional rural banks at 7.22 per cent and all significant at different per cents of probability level.

An over view of results in Table 1 and Fig. 1(b) portrayed that term loan disbursement together by all sources during 2009-10 to 2018-19 was Rs. 1125.89 crore (A increment from Rs. 755.33 crore in $2009-10$ to Rs. 
2584.42 crore in 2016-17 and then declined to 698.77 crore in 2018-19 during the period), which showed an overall declined growth over the years in credit flow by 0.86 per cent. The growth rates in term loan disbursement among different sources showed that commercial banks registered positive growth rate of 3.02 per cent during the period but the co-operatives and RRBs have shown a negative growth rate of 10.69 per cent and 32.15 per cent respectively in term loan disbursement over the years. This is due to lack of refinancing by NABARD to these institutions for term loans and this situation is majorly due to the cases where the eligibility terms are not made fulfilled.

Commercial banks had a major share in disbursement of term loan (Rs. 954.96 crore) contributing 84.82 per cent of the total term credit advancement followed by co-operative banks (Rs. 91.59 crore) contributing 8.13 per cent and regional rural banks (Rs. 79.33 crore) sharing only 7.05 per cent. The proportion of term loans disbursed over the years was found to be very high by commercial banks (ranged between 64.78 per cent and 91.51 per cent). Whereas, the proportion of term loans by co-operatives and regional rural banks declined from 20.49 per cent and 14.73 per cent in $2009-10$ to 8.13 per cent and 7.07 per cent in 2018-19, respectively. This showed that commercial banks were the major sources of term credit.

A perusal of Table 1 and Fig. 1(c) shows that credit disbursement for allied loans together by all the sources from 2009-10 to 2018-19 was about Rs. 916.36 crore, which showed a significant annual growth in credit flow by 3.16 per cent. Among all the three sources, commercial banks had a major share in disbursement allied loan (Rs. 697.66 crore) contributing 76.14 percent to the total credit advancement for allied activities followed by regional rural banks (Rs. 116.43 crore) contributing 12.71 per cent and co-operatives (Rs. 102.24 crore) contributing 11.16 per cent. The share of allied loan by commercial banks in the total allied loan disbursement has increased from 51.61 per cent in 2009-0 to 93.11 per cent in 2018-19, respectively. But, the share of co-operatives and regional rural banks declined from 14.74 per cent and 33.64 per cent to 6.07 per cent and 0.82 per cent respectively over the study period. The growth rates in allied loan disbursement among the sources showed that commercial banks registered significantly highest growth of 10.15 per cent during the period followed by co-operative banks and regional rural banks showing a declined growth rate of 6.53 per cent and 31.72 per cent respectively.

\section{NPA (Non-Performing Assets) STATUS of Odisha}

Odisha Government shifted its focus to augmentation of the farm sector, as education and agriculture term loan has the highest NonPerforming Assets (NPAs) among sectors (Economic Survey 2019) and also added that NPA-level of public sector banks in the State is higher than private sector banks which is excess than prudent and alarming. Education loan and agriculture term loan are found to have the highest NPAs among all the sectors where education loan contributed nearly 13.79 per cent to overall NPA, agricultural term loan and short term crop loan shared 10.8 per cent and 9.91 per cent respectively (SLBC ODISHA 2019).The NPA percentage ranging between 10 per cent to 30.59 per cent and overdue ranging between 17 per cent to 52 per cent for all major schemes are a matter of critical concern as it badly affects the productive recycling of funds," the report summarised. Odisha has 21 public sector banks, 15 private sector banks, two rural banks and one state cooperative bank with a total 5,108 branches. Public sector bank branches constitute 62 per cent of total 
branches. The average population served by a bank branch in the State is 8,868 . Bank branches distribution is skewed as 52 per cent of bank branches serve about 82 per cent of the total population living in rural areas while 48 per cent of bank branches serve only 18 per cent population.

Fig.1(a) Agency wise flow of Crop loan in Odisha

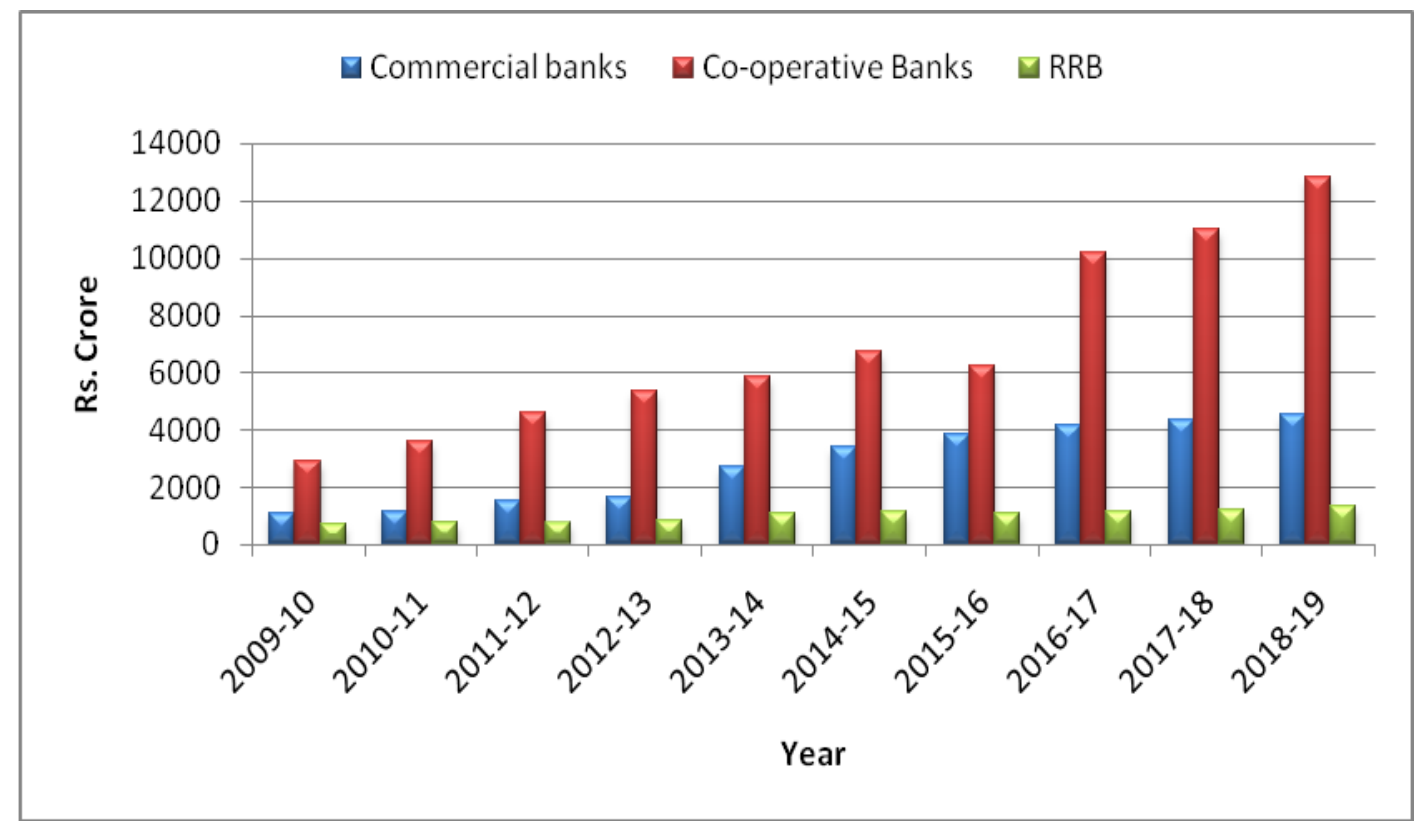

Fig.1(b) Agency wise flow of term loan in Odisha

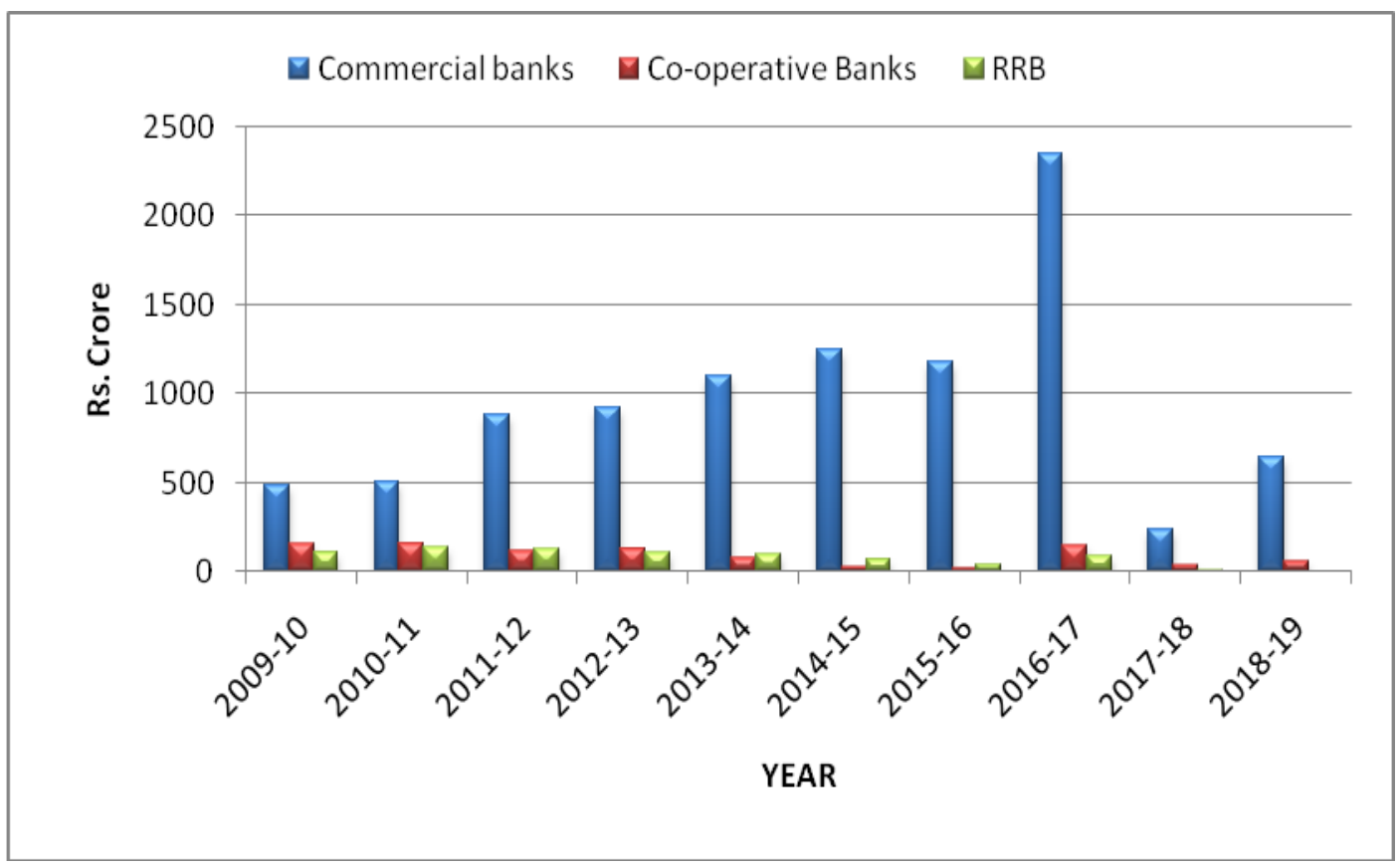


Fig.1(c) Agency wise flow of allied loan in Odisha

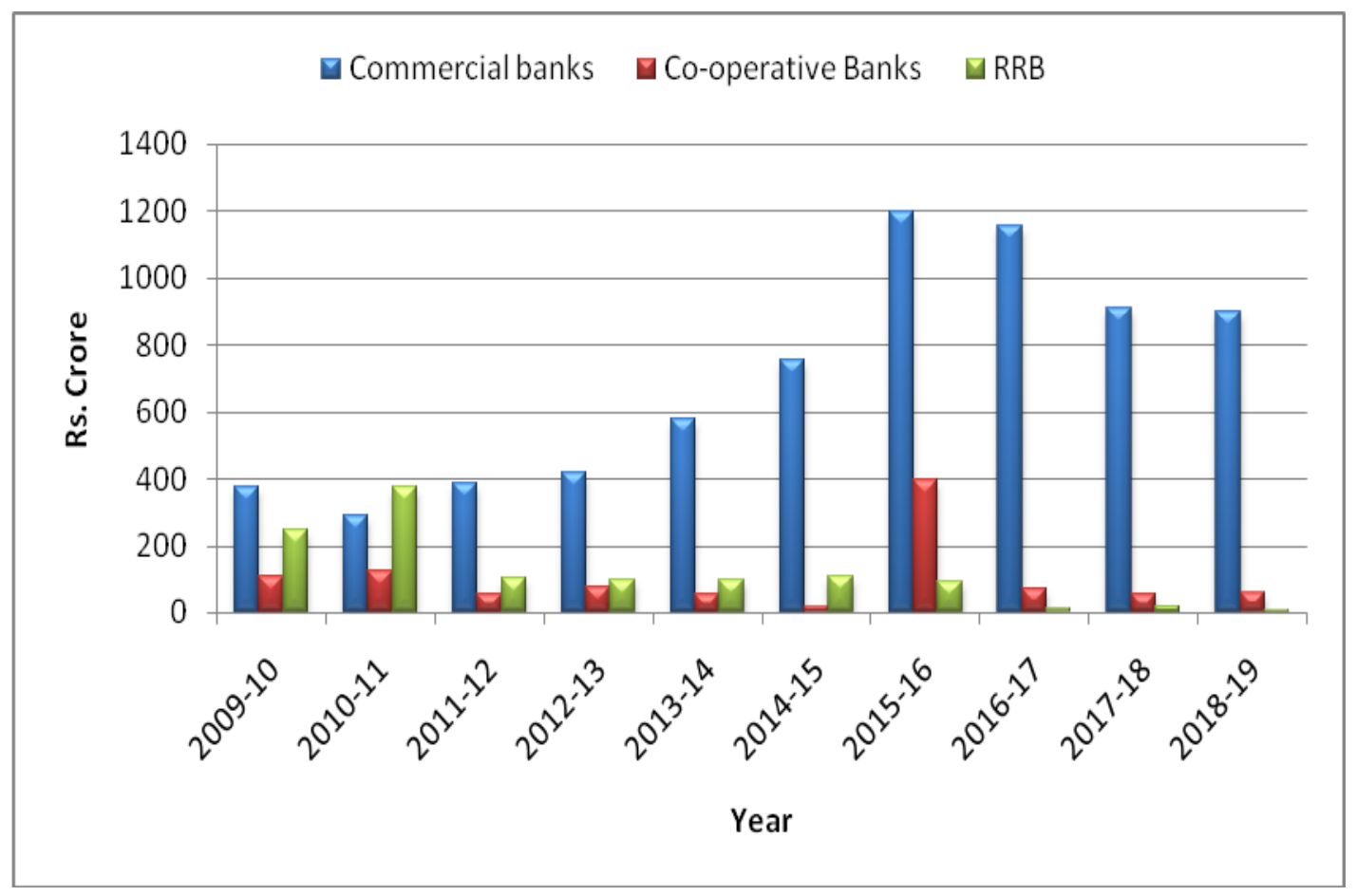

Figure.2(a) Percentage contribution of different sectors in NPA status

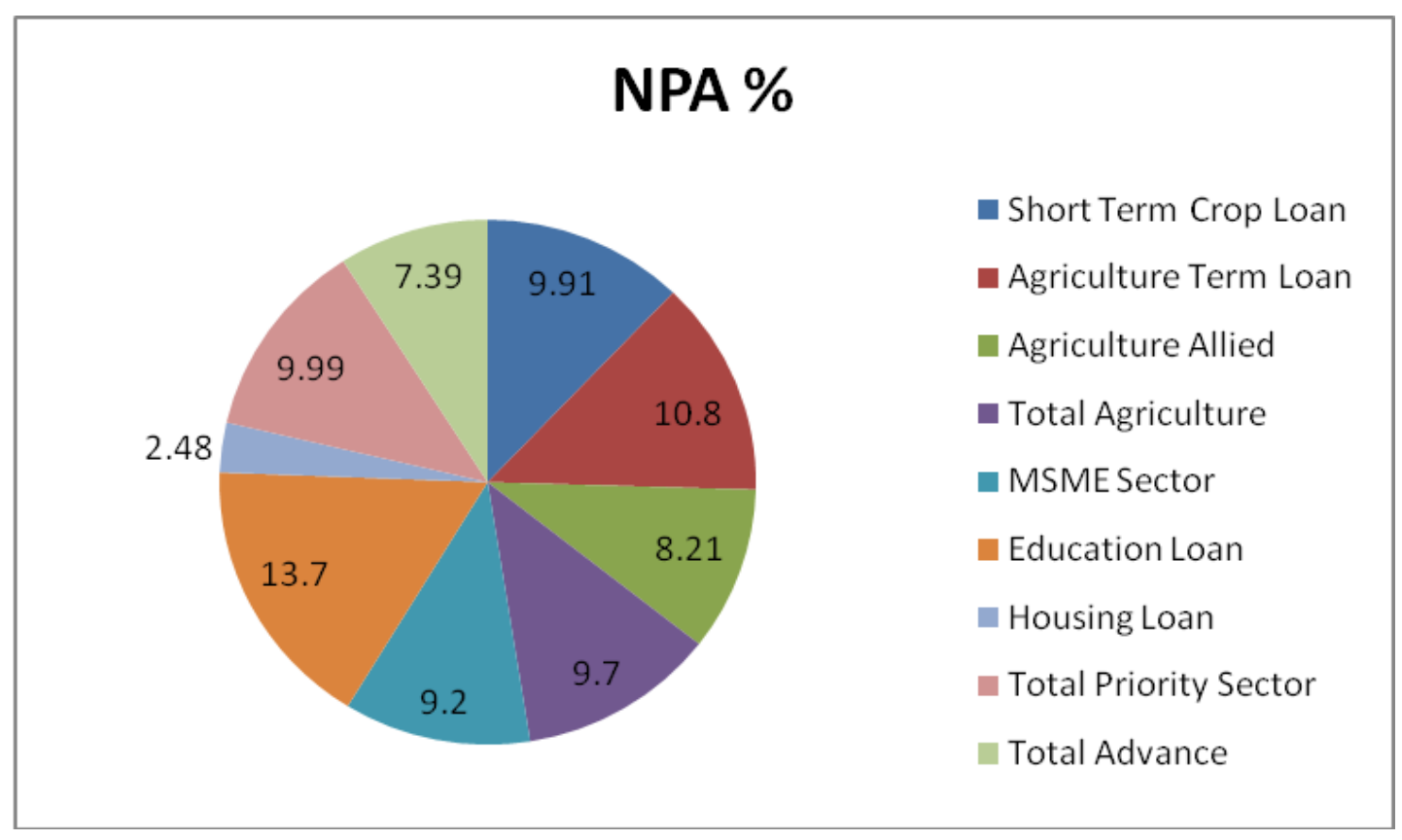


Figure.2(b) Percentage contribution of different sectors in Overdue status

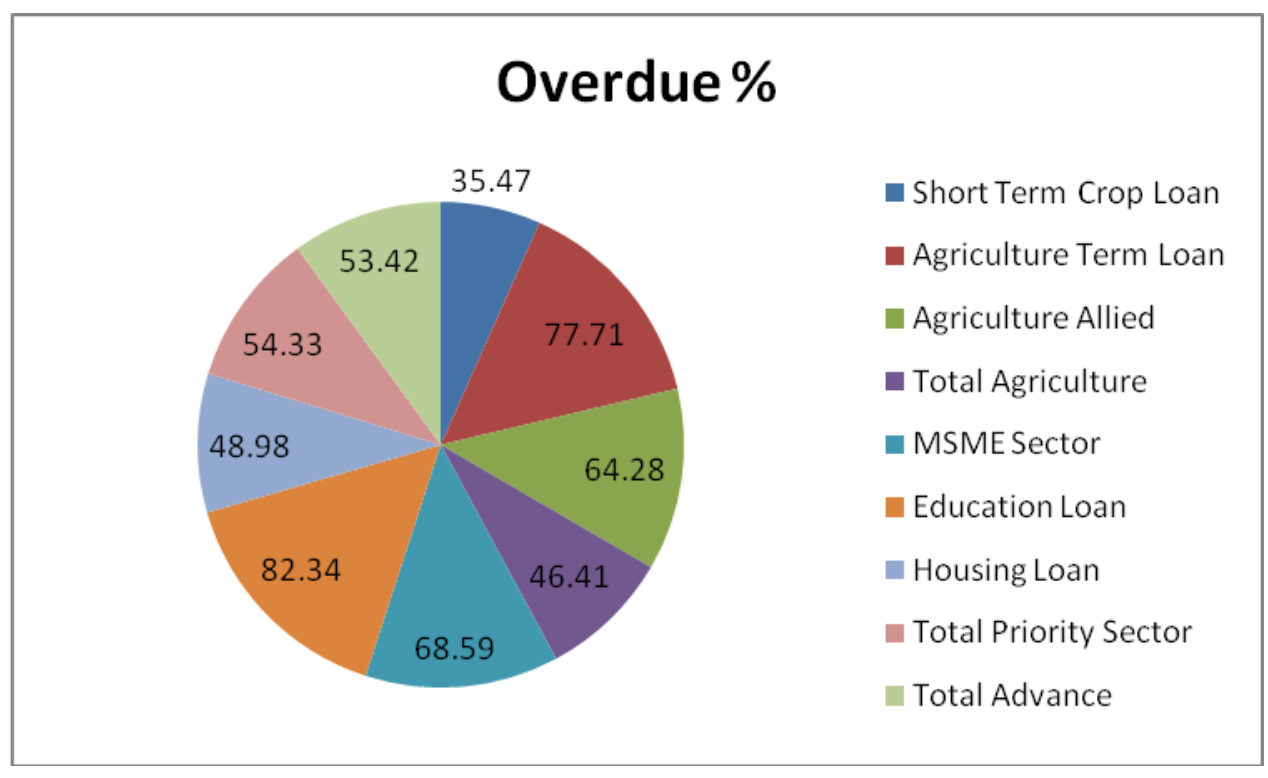

Figure.2(c) Trend of the \%NPA to total outstanding in Odisha

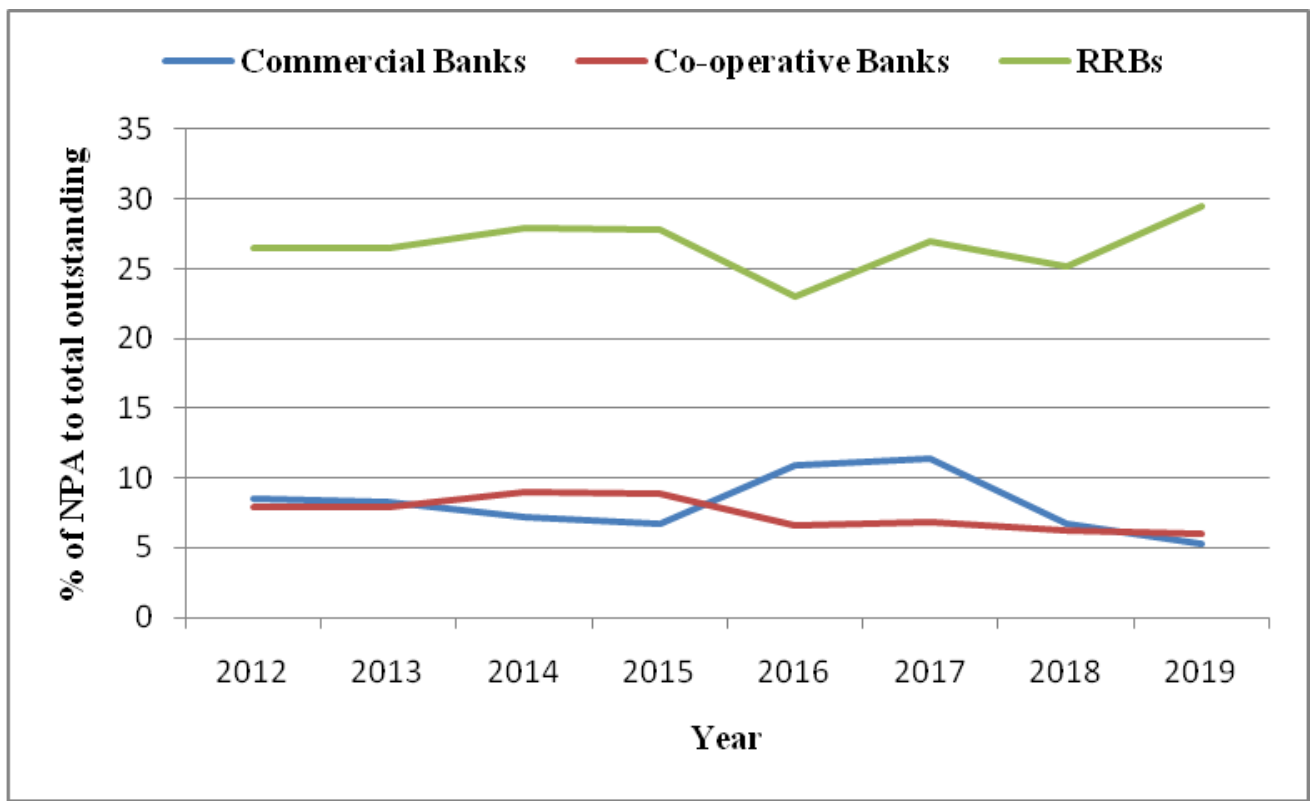

The State Level Bankers' Committee (SLBC) has raised concern on the alarming NPA rate at a time regarding the deteriorating quality of assets. Slowing economic growth and high interest rates have stunted ability to borrowers to repay loans, causing bad loans or NPAs to pile up at banks. Nationwide, sectors like infrastructure, iron \& steel, power, textiles and ship building are the biggest contributors to stressed assets of banks. The trend of percentage of NPA to total outstanding has been outlined in the figure 2(c).

It has been seen from the above figure that the $\%$ NPA to total outstanding was found more in case of regional rural banks as compared to 
commercial and co-operative banks. But this major percentage is due to the role of non priority sector as the total result considering both total priority and non priority sector has been taken in to account for showing the total figure. If only total priority sector has been considered then it has been seen that the sectors like agricultural term loan and education sector have contributed major in NPA status. It has been seen that the percentage of NPA to total outstanding has been declined from 8.57 in 2012 to 7.23 in 2014 and then again raised to 10.96 in 2016 became stable up to 2017-18 and then declined to 5.3 percent in 2019. In case of Cooperative banks since 2015 it started declining continuously.

In conclusion, this paper has analysed status of institutional credit flow to agricultural sector in odisha majorly covering the source wise and purpose wise flow of agricultural credit along with trend in it as well as NPA status of banking sector in state of odisha. It has been found that in case of crop loan major contribution was from co-operative bank followed by commercial and RRBs where as in case of term loan commercial banks played major role followed by co-operative banks and RRBs. Odisha Government shifted its focus to augmentation of the farm sector, as education and agriculture term loan has the highest Non-Performing Assets (NPAs) among sectors. Some important policy implications that could be taken are: (i) The simple but comprehensive record book should be issued to every farmer containing information on land records and institutional transactions. This record book should be made a valid document for presentation to banks and other institutions for availing the necessary services. (ii) Computerization of land records by the state government will facilitate institutional lendings. (iii) Application form should be made simple and in the local language, (iv) All banks should fix one day in a week to deal with and help the farmers in filling up of the application form and completing the formalities, and (v) To minimize the time gap between date of applying for loan and its disbursement, proper maintenance of records with respect to receipt of applications and disbursement of loan should be made mandatory.

\section{References}

Golait, Ramesh (2007) Current issues in agriculture credit in India: An assessment, Reserve Bank of India Occasional Papers, 28, No. 1.

Khan, H. R. (2008), "Financing Agriculture in Orissa: Issues, Options and Challenges", Lecture delivered at the valedictory session of the Programme on Financing Agriculture in Orissa organised by the College of Agricultural Banking (CAB), Pune in Bhubaneswar.

Kumar, Anjani, Singh, Dhiraj K. and Kumar, P., 2007, Performance of rural credit and factors affecting the choice of credit sources, Indian J. Agric. Econs., 62(3): 297-313.

Mohan, Rakesh (2004) Agricultural credit in India: Status, issues and future agenda, Reserve Bank of India Bulletin, November.

NABARD State Focus Paper (various issues) National Bank for Agriculture and Rural Development, Odisha.

Odisha Economic Survey (2019) Planning and Convergence Department. Directorate of Economics and Statistics, Government of Odisha.

Reserve Bank of India (2008a) Handbook of Statistics on the Indian Economy, 200708, Mumbai.

Shraddha, S. (2013) Financial innovation in Indian agricultural credit market: Progress and performance of Kisan Credit Card. International Journal of Ongoing Research in Management and Information Technology, 13: 1-3.

SLBC (2019) SLBC $157^{\text {th }}$ meeting proceedings, State level banker's Committee of Odisha. 


\section{How to cite this article:}

Shruti Mohapatra and Raj Kishore Mishra. 2020. Status of Institutional Credit Disbursement of Agricultural Sector in Odisha, India. Int.J.Curr.Microbiol.App.Sci. 9(07): 2057-2065. doi: https://doi.org/10.20546/ijcmas.2020.907.237 